Indonesian Journal of Nutrition and Dietetics Vol. 7, No. 2, 2019: 51-57
Available online at: http://ejournal.almaata.ac.id/index.php/IJND DOI : http://dx.doi.org/10.21927/ijnd.2019.7(2).51-57

\title{
Free radical scavenging and cytotoxic assay of soursop fruit juice (Annona muricata Linn.) on cervical cancer cell lines (HeLa)
}

Rahma Micho Widyanto ${ }^{1}$, Rifanty Meydiana Rachmawati Putri ${ }^{1}$, Fuadiyah Nila Kurniasari $^{1}$, Yunimar $^{2}$, Budi Utomo $^{3}$

${ }^{1}$ Nutrition Science Program, Faculty of Medicine.

Universitas Brawijaya. Jalan Veteran, Malang 65145, East Java, Indonesia

${ }^{2}$ Research Institute for Citrus and Subtropical Horticulture Crops.

Jalan Raya Tlekung No.1, Junrejo, Kota Batu 63105. Indonesia

${ }^{3}$ Faculty of Animal Husbandry, Nusantara University, Jalan KH Achmad Dahlan 76

Mojoroto, 64112 Kediri, Indonesia

${ }^{*}$ Corresponding author: micho@ub.ac.id

\begin{abstract}
ABSTRAK
Latar belakang: Kanker serviks merupakan penyakit yang menduduki posisi kedua penyebab kematian pada wanita. Berbagai terapi pendukung mulai dikembangkan, seperti melalui bahan makanan yang dipercaya memiliki efek anti-kanker. Buah sirsak disebut memiliki kandungan fitokimia seperti Annonaceous acetogenin, flavonoid dan fenol yang bermanfaat sebagai anti-kanker.

Tujuan: Penelitian ini dilakukan untuk mengetahui potensi anti-oksidan dan sitotoksisitas dari sari buah sirsak pada sel HeLa secara in vitro.

Metode: Penelitian ini dilakukan dengan membuat sari buah sirsak dengan cara diblender kemudian dikeringkan dengan metode freeze-drying, yang kemudian dilanjutkan dengan uji 2,2-diphenyl-1picrylhydrazyl (DPPH) untuk mengetahui potensi penghambatan radikal bebas, dan potensi sitotoksisitas melalui uji MTT (3-(4,5-dimetiltiazol-2-il)-2,5-difenitetrazolium bromide) assay pada sel kanker serviks HeLa. Hasil: Hasil uji aktivitas anti-oksidan menunjukkan persamaan regresi linier $(y=0,0149 x-2,8812)$ dan nilai perhitungan $I C_{50}$ sari buah sirsak sebesar $3549 \mu \mathrm{g} / \mathrm{mL}$ dan hasil uji sitotoksisitas menunjukkan persamaan regresi linier $(y=0,0197 x+0,3101)$ dan nilai perhitungan $I C_{50}$ sari buah sirsak pada sel HeLa sebesar 2522,33 $\mu \mathrm{g} / \mathrm{mL}$.
\end{abstract}

Kesimpulan: Sari buah sirsak memiliki aktivitas anti-oksidan yang sangat rendah dan tidak berpotensi sebagai anti-kanker terhadap sel HeLa secara in vitro.

KATA KUNCI : Annona muricata Linn, anti-oksidan, kanker, sitotoksisitas

\begin{abstract}
Background: Cervical cancer is the second leading cause of death in women. Various supporting therapies have been developed, such as through food ingredients which are believed to have anti-cancer effects. Soursop is known to be high phytochemical content such as Annonaceous acetogenin, flavonoid and phenols which are useful as anti-cancer.

Objectives: This research was conducted to determine the antioxidant and cytotoxic activity of soursop juice on HeLa cell lines.

Methods: This study started by making the soursop fruit extract by blending then dried with freeze-drying method, and then proceed with 2.2-diphenyl-1-picrylhydrazyl (DPPH) assay to determine the potential free radical scavenging activity, cytotoxic potential activity in vitro through MTT (3-(4,5-dimethylthiazol-2il)-2,5-difenitetrazolium bromide) assay on HeLa cell lines.

Results: The $I C_{50}$ antioxidant activity of soursop fruit extract is $3549 \mu \mathrm{g} / \mathrm{mL}$ with linear regression equation $(y=0.0149 x-2.8812)$ and the $I C_{50}$ cytotoxicity test of soursop fruit extracton HeLa was $2522,33 \mu \mathrm{g} / \mathrm{mL}$ with linier regression equation $(y=0.0197 x+0.3101)$.

Conclusion: The conclusion in this study is that soursop fruit extract has very low antioxidant activity and has no in vitro potential effect as an anti-cancer on HeLa cell lines.
\end{abstract}

KEYWORDS : Annona muricata Linn, antioxidant, cancer, cytotoxic 


\section{INTRODUCTION}

Cancer is a condition of changes in cell structure and function, which results in uncontrolled or abnormal cell division processes (1). Cancer is the second largest cause of death in the world. In Indonesia the prevalence of cancer is reported at 1.4 per 1000 population or around 330,000 people (2).

One type of cancer is cervical cancer, this cancer is the second most common type of cancer after breast cancer in women of reproductive age in Indonesia. Since 2000-2012 the number of cervical cancers has continued to increase and has resulted in $28 \%$ of deaths in Indonesia (3). Various types of treatment were applied to overcome this, but the results were not effective enough and had several downside (1).

In response to these conditions, several studies have been conducted to find supportive therapy through food to overcome cancer, because there are several food ingredients believed to be useful as anti-cancer. One example is soursop or Annona muricata Linn. (A. muricata). In soursop fruit, the main substance is carbohydrates (mainly fructose) and the dominant vitamin is vitamin C (20 $\mathrm{mg} / 100$ grams) which acts as an antioxidant (4).

The soursop plants also consist of Annonaceous acetogenins, which there were more than 100 types of Annonaceous acetogenins were founf in the leaves, bark, roots, and fruit. This compound has been scientifically proven to be an anti-cancer and anti-tumor because it has toxic effects on cancer cells without damaging healthy cells (5).

Anti-cancer potential can be identified by conducting cytotoxic tests. The testing of the antineoplastic activity of a compound can be detected in vitro as indicated by $\mathrm{IC}_{50}$ values. In previous studies, cytotoxic tests using methanol extract of fruit, leaves and soursop seeds have been carried out on blood cancer cells (CCRF-CEM cell) with $\mathrm{IC}_{50}$ values of (4.58 \pm 0.25$),(0.57 \pm 0,02)$, and $(0.36 \pm 0.03) \mu \mathrm{g}$ $/ \mathrm{mL}$, respectively (6).

While the portion of the soursop fruit that is widely consumed is the flesh and is usually processed into soursop juice, there is still no cytotoxic effect test of soursop flesh on cervical cancer cells. While the portion of the soursop tree that is widely consumed is part of the fruit and is usually processed into soursop juice. Therefore, to determine the presence of anti-cancer potential of soursop juice in HeLa cells, it is necessary to test the antioxidant and cytotoxic activity.

This study aims to determine the value of antioxidant activity and the citotoxic potential of soursop juice (A. muricata) on cervical cancer cells (HeLa).

\section{MATERIALS AND METHODS}

\section{Preparation of sample}

The material used in this study was soursop fruit which was purchased from plantations in the Materia Medika, East Java, Indonesia. The criteria of soursop fruit include \pm 12 weeks of fruitage, yellowish-green fruit skin, soft fruit, not sharp and far apart, and fragrant soursop fruit. The fruits were blended then squeezed using a filter cloth, then dried using freeze-drying method. The extracts were stored at $4^{\circ} \mathrm{C}$ for further experiments $(7,8)$. DPPH Free Radical Scavenging Activity Assay.

One $\mathrm{ml}$ of $A$. muricata extract were introduced into a tube then added $3 \mathrm{ml}$ DPPH solution. The mixture then shaken using vortex and measured with spectrophotometer at $517 \mathrm{~nm}$. Free radical scavenging activity of the sample was measured according to ${ }^{9}$ :

Scavenging $\%=(A c-A s) / A c \times 100$.

As: sample absorbance

Ac: negative control absorbance (without sample)

\section{Cytotoxic Assay}

HeLa cells were cultured on RPMI medium which added $10 \%$ FBS, and $1 \%$ penicillinstreptomycin. Cells were then incubated at $37^{\circ}$ $\mathrm{C}$ and $5 \% \mathrm{CO}_{2}$. HeLa cells were harvested when they reached $80 \%$ confluent and were planted in the 96 -well plate, 5.000 cells for each well ${ }^{10}$. After 24 hours of incubation, the cells are then treated with $A$. muricata extract with various concentrations $(62.5 ; 125 ; 250 ; 500$; and $1000 \mu \mathrm{g} / \mathrm{mL})$ for 24 hours.

MTT (3- (4,5-dimethylthiazol-2-yl) $-2,5$-diphenyltetrazolium bromide) is used to 
determine cell viability. 20 ul MTT was added to each well and incubated with temperature $37^{\circ} \mathrm{C}, 5 \%$ $\mathrm{CO}_{2}$ under dark conditions for 4 hours. The reaction was stopped by adding $10 \%$ SDS. The absorbance is measured using a microplate reader at $570 \mathrm{~nm}^{11}$. The data were analyzed using ANOVA, followed by Turkey post hoc test.To determine the value of inhibitory concentration $\left(\mathrm{IC}_{50}\right)$, a Probit Analysis was used with Excell Microsoft Office 2010.

\section{RESULTS}

\section{Soursop Fruit Extract}

Soursop fruit juice made from one fruit of soursop weighing $910 \mathrm{~g}$. Furthermore, the fruit flesh is separated from the skin and seeds, and the net weight of fruit flesh is 691 grams. Followed by the process of blending and then filtered with a filter cloth, and obtained as much as $450 \mathrm{ml}$ of soursop juice. $100 \mathrm{ml}$ of soursop juice were taken for the drying process freeze-drying. Where from $100 \mathrm{ml}$ of soursop fruit juice the dry yield is 19 grams.
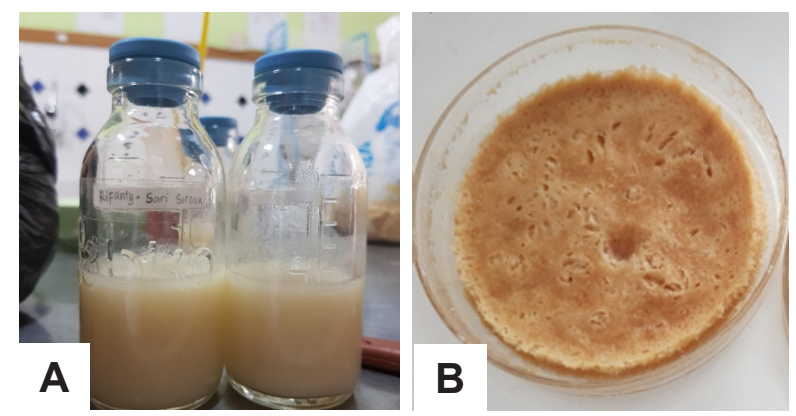

Figure 1. Sample soursop juice. Soursop fruit that has been blended and filtered (A) and the sample results of the freeze-dry soursop extract (B)

\section{DPPH Free Radical Scavenging Activity Assay}

The antioxidant activity test on soursop juice was carried out with 5 concentrations, namely 500 ; 750; 1000; 1250; and $1500 \mu \mathrm{g} / \mathrm{mL}$. The percentage of inhibition is higher in proportion to the higher concentration of soursop juice, this is presented in Table 1. The highest percentage of inhibition is at a concentration of $1500 \mu \mathrm{g} / \mathrm{mL}$, which is equal to $19.83 \%$. A linear regression curve was made from the data concentration and the percentage of inhibition (Figure 2), which is used to calculate the
IC50 value. The IC50 value obtained was 3549.074 $\mathrm{ug} / \mathrm{mL}$.

Table 1. Percentage of Soursop Fruit Extract in DPPH Test

\begin{tabular}{cccc}
\hline $\begin{array}{c}\text { Concentration } \\
(\boldsymbol{\mu g} / \mathrm{mL})\end{array}$ & Absorbance & $\begin{array}{c}\% \\
\text { Inhibition }\end{array}$ & $\begin{array}{c}\mathrm{IC}_{50} \\
(\boldsymbol{\mu g} / \mathbf{m L})\end{array}$ \\
\hline Blank & 1.069 & 0.00 & \\
$\mathbf{5 0 0}$ & 1.015 & 5.05 & \\
$\mathbf{7 5 0}$ & 0.993 & 7.11 & 3549 \\
$\mathbf{1 0 0 0}$ & 0.928 & 13.19 & \\
$\mathbf{1 2 5 0}$ & 0.912 & 14.69 & \\
$\mathbf{1 5 0 0}$ & 0.857 & 19.83 & \\
\hline
\end{tabular}

\section{Soursop Fruit Extract}

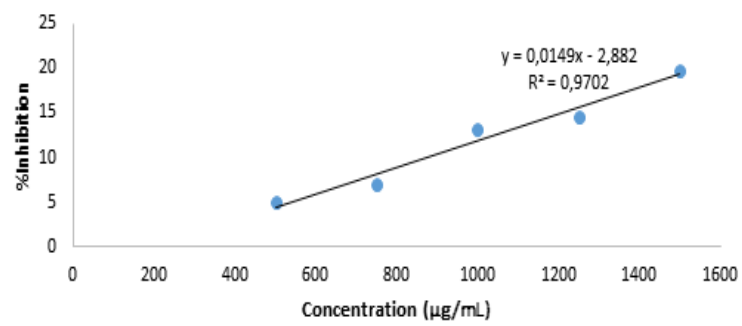

Figure 2. Linear Regression Curve of Soursop Fruit Extract DPPH Test

\section{Cytotoxicity Assay}

This test was carried out with 5 concentrations namely, $62.5 ; 125 ; 250 ; 500$; and $1000 \mu \mathrm{g} / \mathrm{mL}$, and incubated for 24 hours. The results then were used to read the absorbance using an ELISA reader with a wavelength of $570 \mathrm{~nm}$. The proliferation percentage is presented in Table 2. The standard curve used to calculate the $I C_{50}$ value is shown in Figure 3 . Furthermore, the calculation of the $I_{50}$ value is obtained at $2522.33 \mu \mathrm{g} / \mathrm{mL}$.

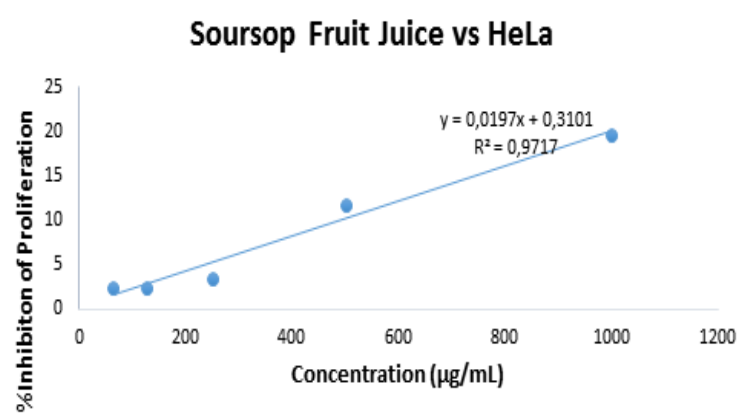

Figure 3. Linear Regression Curve of MTT Assay Cytotoxicity Test 
Table 2. Inhibition of Proliferation of Soursop Fruit Juice in HeLa Cells

\begin{tabular}{ccccccc}
\hline Sample & $\begin{array}{c}\text { Concentration } \\
(\boldsymbol{\mu g} / \mathbf{m L})\end{array}$ & $\begin{array}{c}\text { \% Inhibition } \\
\text { Concentration 1 }\end{array}$ & $\begin{array}{c}\text { \% Inhibition } \\
\text { Concentration 2 }\end{array}$ & $\begin{array}{c}\text { \% Inhibition } \\
\text { Concentration 3 }\end{array}$ & $\begin{array}{c}\text { Mean } \\
\text { Value }\end{array}$ & SD \\
\hline \multirow{3}{*}{ Soursop } & 62.5 & 3.737 & 1.823 & 1.823 & 2.461 & 1.105 \\
Fruit & 125 & 5.652 & 0.729 & 0.729 & 2.370 & 2.842 \\
Extract & 250 & 1.459 & 3.191 & 5.925 & 3.525 & 2.251 \\
& 500 & 14.950 & 8.660 & 11.668 & 11.759 & 3.146 \\
& 1000 & 16.864 & 22.607 & 19.599 & 19.690 & 2.873 \\
\hline
\end{tabular}

\section{DISCUSSION}

In general, extraction can be done with polar solvents (water, ethanol, methanol, etc.) or nonpolar solvents (petroleum ether, chloroform, etc.), depending on the polarity of the compounds to be extracted, commonly called the principle of like dissolves like ${ }^{12}$. Commonly, to test the cytotoxicity, the extraction process of soursop plants was done with polar solvents. Like the cytotoxic test on soursop seeds, the extraction process on soursop seeds was carried out by maceration method using $96 \%$ ethanol to extract the chemical compounds contained in soursop seeds ${ }^{13}$. Likewise in other studies extraction of leaves, seeds and soursop fruit using methanol solvent to obtain crude extract ${ }^{6}$. This is because the chemical compounds that want to be extracted from the soursop plant for cytotoxicity tests have polar properties, including alkaloids, acetogenin, flavonoids, phenols, and other compounds such as vitamin $\mathrm{C}$.

The cytotoxic of soursop juice against cervical cancer cells (HeLa) was analyzed by the MTT Assay method. The results obtained were the highest proliferation inhibition occurred at a concentration of $1000 \mu \mathrm{g} / \mathrm{mL}$ and $\mathrm{IC}_{50}$ values of $2522.33 \mu \mathrm{g} / \mathrm{mL}$. Based on U.S National Cancer Institute $(\mathrm{NCl})$ a crude extract is considered to have cytotoxicity activity in vitro if it has an $\mathrm{IC}_{50}$ value of less than 20 $\mu \mathrm{g} / \mathrm{mL}$ and less than $4 \mu \mathrm{g} / \mathrm{mL}$ for pure compounds ${ }^{14}$. However, another study said that have active anticancer properties with an $\mathrm{IC}_{50}$ value of $23,649 \mu \mathrm{g} /$ $\mathrm{mL}$ in HeLa cells, $110,403 \mu \mathrm{g} / \mathrm{mL}$ in HepG2 cells, and anti-proliferative with $\mathrm{IC}_{50}$ values of $220 \mu \mathrm{g} / \mathrm{mL}$ in PC3 prostate cancer cells ${ }^{15,10}$.

Based on the references above, it shows that anti-cancer activity still does not have a definite cutoff. However, when compared to the results of the cytotoxic test of soursop juice, the results obtained were too high, so it could be concluded that the soursop juice in this study did not have cytotoxic activity and had no potential as an anti-cancer agent in vitro against cervical cancer cells (HeLa).

It caused by several factors, one of which is the phytochemical content in soursop fruit. In general, cytotoxic studies more often use soursop leaves than fruit, this is due to the more phytochemical content in it. The phytochemical content found in soursop fruit between alkaloids, Annonaceous acetogenin and phenol, in which if compared with its content in soursop leaves shows that each of the phytochemical classes has a smaller variation in fruit 5 . In addition it has been proven from cytotoxic studies using samples of leaves and soursop fruit with water solvents on Raji cells, showing $I C_{50}$ values of $73.1 \pm 1.4 \mu \mathrm{g} / \mathrm{mL}$ and $385.2 \pm 1.7 \mu \mathrm{g} / \mathrm{mL}^{16}$. Although the content in soursop leaves has proven to be more varied and has the potential as an anticancer, soursop leaves are not a normal part of daily consumption as food.

Based on the results of similar studies using samples in the form of food, $I C_{50}$ values of the ethanol extract of melon fruit were $23,649 \mu \mathrm{g} / \mathrm{mL}$ in HeLa cells and $110,403 \mu \mathrm{g} / \mathrm{mL}$ in HepG2 cells ${ }^{10}$. This shows that melon fruit extract has much better anti-cancer properties compared to soursop juice. In other studies it has also been proven that melons have the potential as anti-cancer in PC3 prostate cancer cells and RCM-1 colon cancer cells, because they contain MTPE which functions as an anticancer ${ }^{15,17}$.

The extraction process can also be influential in extracting compounds that play a role in the cytotoxic test. This is because the polarity of the selected solvent can determine what solute will be obtained $^{18}$. In a similar study namely cytotoxic test of 
white blood cancer cells using fruit samples, leaves and soursop seeds were extracted with methanol solvents and each had an $\mathrm{IC}_{50}$ value of $4.58 \pm 0.25$ $\mu \mathrm{g} / \mathrm{mL}, 0.57 \pm 0.02 \mu \mathrm{g} / \mathrm{mL}$, and $0.36 \pm 0.03 \mu \mathrm{g} / \mathrm{mL}^{6}$. It shows that the methanol solvent is able to extract phytochemical compounds in the fruit, leaves and soursop seeds well so that it has good cytotoxic activity also on white blood cancer cells.

Another study using samples of soursop leaves with ethanol and water solvents showed $\mathrm{IC}_{50}$ values of $88.79 \mu \mathrm{g} / \mathrm{mL}$ and $682.88 \mu \mathrm{g} / \mathrm{mL}$ for 24 hours incubation, and at $14.68 \mu \mathrm{g} / \mathrm{mL}$ and $538.22 \mu \mathrm{g} /$ $\mathrm{mL}$ for 48 hours incubation ${ }^{19}$. In this study showed that ethanol solvents were better at extracting phytochemical compounds in soursop leaves. Then it can be concluded that there is no one type of solvent that is the best, this is influenced by each level of polarity of the substance you want to extract.

The freeze-drying process in various types of conditions can significantly reduce ascorbic acid content ${ }^{20}$. This is evidenced by the reduction in ascorbic acid content by $17 \%$ in dried blueberries after 14 days of storage when compared to ascorbic acid content in fresh blueberries. This condition is caused by ascorbic acid is one component of nutrients in food ingredients that are classified as unstable with the influence of light, temperature, osmotic pressure and others. Where it is known that one of the important ingredients in soursop fruit is vitamin C of $20 \mathrm{mg} / 100$ grams which is also useful as an antioxidant ${ }^{2}$. So that in this cytotoxic test it can be said that the vitamin $\mathrm{C}$ content in dried soursop juice is reduced or less than in fresh condition, so it also affects its cytotoxic properties.

Other processing is also thought to affect the phytochemical content in soursop fruit. In a study, blending and juicing on several fruits were carried out to determine the difference in phytochemical content in the fruit ${ }^{21}$. In the final product blending process obtained is the form of pulp from all ingredients that are blended, while juicing produces the final product in the form of juice only. After phytochemical content testing showed that the fruit through the blending process has better flavonoid and polyphenol content, which is related to the final result which is in the form of fruit pulp ${ }^{21}$.
In addition to the factors described above, the low cytotoxic of soursop juice is supported by its antioxidant activity which is also classified as very weak, which is $3549 \mu \mathrm{g} / \mathrm{mL}$. Based on existing research it is stated that there is a relationship between antioxidant activity and anti-cancer potential, where samples that have high anti-cancer potential also have high antioxidant activity ${ }^{22}$.

In this study, the results of the antioxidant activity test showed a very high value of $3549 \mu \mathrm{g} / \mathrm{mL}$. So it can be concluded that the antioxidant activity in soursop juice is very weak. According to Blois (1985) the strength of antioxidant activity is said to be very strong if the $\mathrm{IC}_{50}$ value $<50 \mu \mathrm{g} / \mathrm{mL}$ is strong if the $\mathrm{IC}_{50}$ value is $50-100 \mu \mathrm{g} / \mathrm{mL}$, moderate if the $I_{50}$ value is $101-150 \mu \mathrm{g} / \mathrm{mL}$, and weak if the $I_{50}$ value is $>150 \mu \mathrm{g} / \mathrm{mL}$. The lower the $\mathrm{IC}_{50}$ value, the greater the power to inhibit free radicals ${ }^{23}$.

The factors that influence antioxidant activity are the same as factors affecting cytotoxicity testing. Antioxidant activity can be influenced by the type of solvent used ${ }^{24}$. In his research, the antioxidant activity of matoa leaf extract showed that matoa leaf extract with acetone solvent was the most powerful compared to methanol, ethanol, water and isopropanol solvents. This shows that phytochemical compounds in matoa leaves which play a role in inhibiting base radicals can be extracted well in acetone solvents ${ }^{24}$.

Likewise in other studies, comparing antioxidant activity in Annona squamosa fruit extracts with water solvents and also methanol showed IC ${ }_{50}$ results of $157.2 \mu \mathrm{g} / \mathrm{mL}$ and $135.2 \mu \mathrm{g} / \mathrm{mL}$ respectively ${ }^{25}$. This shows that antioxidant activity obtained from methanol extract is slightly stronger than water extract. Which means that methanol solvents can extract well the total content of phenols and flavonoids contained in it.

Freeze-drying and processing that affect the final product also play a role in the low phytochemical content in the sample used. Where freeze-drying in various conditions proved to be able to reduce ascorbic acid content in a sample ${ }^{20}$. While the blending process that produces fruit pulp will produce better flavonoids and polyphenols compared to the processing of juicing, which results in fruit juice alone ${ }^{21}$. 
The antioxidant activity of soursop juice is much lower when compared to ascorbic acid as a positive control. This is because soursop juice is a crude extract, while ascorbic acid is a standard control in the form of very pure compounds ${ }^{26}$.

\section{CONCLUSION AND RECOMMENDATION}

From the results of data analysis in this study, it can be concluded that soursop juice has very low antioxidant activity and is not proven to have anticancer potential in HeLa cervical cancer cells in vitro.

\section{Recommendation}

1. Adding a phytochemical content test from soursop juice, including the content of vitamin $C$, flavonoids and phenol

2. Test the soursop juice on other cancer cells

3. Using samples in the form of whole fruit or in the results of the blender without squeezing

\section{ACKNOWLEDGEMENTS}

The authors acknowledge gratefully for support from Food Organizing Laboratory of the Nutrition Science Study Program, Faculty of Medicine, University of Brawijaya; Research Institute for Citrus and Subtropical Horticulture Crops, Malang, Indonesia; and Centre for Pharmaceutical and Medical Technology, The Agency for the Assessment and Application of Technology (BPPT), Indonesia.

\section{REFERENCES}

1. Kelvin, J. F. dan Tyson, L. B. 2011. 100 TanyaJawab Mengenai Gejala Kanker Dan Efek Samping Pegobatan Kanker, Edisi Kedua. Jakarta Barat: PT Indeks

2. Kemenkes RI. 2013. Riset Kesehatan Dasar (RISKESDAS) 2013. Laporan Nasional 2013, pp. 1-384. doi: 1 Desember 2013.

3. Nurcahyanti, A. D. R. Cervical Cancer: The Case in Indonesia and Natural Product- Based Therapy. Journal of Cancer Biology \& Research, 2016; 4: 1-7.
4. Joe, Wulan. 2012. Dahsyatnya Khasiat Sirsak Untuk Banyak Penyakit Yang Mematikan. Yogyakarta: ANDI

5. Moghadamtousi, S. Z., Fadaeinasab, M., Nikzad, S., Mohan, G., Ali, H. M., and Kadir, H. A. Annona muricata (Annonaceae): A Review of Its Traditional Uses, Isolated Acetogenins and Biological Activities. International Journal of Molecular Sciences, 2015; 16(7): 15625-15658.

6. Kuete, V., Dzotam, J. K., Voukeng, I. K., Fankam, A. G., and Efferth, T. Cytotoxicity of methanol extracts of Annona muricata, Passiflora edulis and nine other Cameroonian medicinal plants towards multi-factorial drug-resistant cancer cell lines. SpringerPlus. Springer International Publishing, 2016; 5(1): 1-12.

7. Hariyadi, P. 2013. Freeze Drying Technology : for Better Quality \& Flavor of Dried Products. Foodreview Indonesia, VIII(2): 52-57.

8. Koswara, S. 2009. Teknologi Pengolahan Sayuran Dan Buah-Buahan (Teori Dan Praktek). e-Book Pangan, pp. 1-59.

9. J. Wang, X. Zhou, Y. Cao, J. Xiao, E. Ma, Y. Deng, and $D$. Chen, "The antitumor activities of cucurbitacin liposome for injection both in vitro and in vivo," Asian J. Trad Med, vol. 2, no. 3, pp. 98-103, May 2007

10. Widowati, W., Widyanto, R. M.,Laksmitawati, D. R., Erawijantari, P. P., Wijaya, L. And Sandra, F. Phytochemical, Free Radical Scavenging and Cytotoxic Assay of Cucumis Melo L. Extract and $\beta$-Carotene. Journal of Advanced Agricultural Technologies, 2016, 2(2): 114-119.

11. Widowati, W., Wijaya, L., Laksmitawati, D.R., Widyanto,R.M., Erawijantari,P.P.,Fauziah,N.,Ba chtiar,I., and Sandra. F. Tea Flavonoids Induced Differentiation of Peripheral Blood-derived Mononuclear Cells into Peripheral Blood-derived Endothelial Progenitor Cells and Suppressed Intracellular Reactive Oxygen Species Level of Peripheral Blood-derived Endothelial Progenitor Cells. Nat Prod Sci. 2016 Jun;22(2):87-92.

12. Mukhriani. Ekstraksi, Pemisahan Senyawa, dan Identifikasi Senyawa Aktif. Jurnal Kesehatan, 2014; VII(2): 361-367. 
13. Arifianti, L., Sukardiman, Studiawan, H., Rakhmawati, and Megawati L. Uji Aktivitas Ekstrak Biji Sirsak (Annona muricata L.) Terhadap Sel Kanker Mamalia Secara In Vitro. Jurnal Farmasi dan IImu Kefarmasian Indonesia, 2014; 1(2): 63-66.

14. Sriwiriyajan, S., Ninpesh, T., Sukpondma, Y., Nasomyon, T. and Graidist, P. Cytotoxicity Screening of Plants of Genus Piper in Breast Cancer Cell Lines. Tropical Journal of Pharmaceutical Research, 2014, 13(6): 921-928.

15. Ittiyavirah, S. P. and Cheriyan, S. Evaluation of Ethanolic Extract of Cucumis melo L . for Inflammation and Hyperplasia of Prostate. International Journal of Nutrition, Pharmacology, Neurological Diseases, 2014; 4(4): 224-230.

16. Roduan, M. R. M., Hamid, A. H., Kqueen, C. Y. and Mohtarrudin, N. Cytotoxicity, Antitumorpromoting and Antioxidant Activities of Annona muricata in vitro. Journal of Herbal Medicine, Elsevier $\mathrm{GmbH}, 2018$, pp.1-24.

17. Nakamura, Y., Nakayama, Y., Ando, H., Tanaka, A., Matsuo, S. O., Upham, B. L., et al. 3-Methylthiopropionic Acid Ethyl Ester, Isolated from Katsura-uri (Japanese pickling melon, Cucumis melo var. conomon), Enhanced Differentiation in Human Colon Cancer Cells. Journal of Agriculture and Food Chemystry, 2008; 56(9): 2977-2984.

18. Mukhriani. Ekstraksi, Pemisahan Senyawa, dan Identifikasi Senyawa Aktif. Jurnal Kesehatan, 2014; VII(2): 361-367

19. Endrini, S., Suherman and Widowati, W. Annona muricata Leaves Have Strongest Cytotoxic Activity Against Breast Cancer Cells. Universa Medicina, 2014; 33(3): 179-184.

20. Reyes, A., Evseev, A., Mahn, A., Bubnovich, V., Bustos, R. and Scheuermann, E. Effect of Operating Conditions in Freeze-drying on The Nutritional Properties of Blueberries.
International Journal of Food Science and Nutrition, 2015; pp. 1-16.

21. Pyo, Y., Jin, Y. and Hwang, J. Comparison of the Effects of Blending and Juicing on the Phytochemicals Contents and Antioxidant Capacity of Typical Korean Kernel Fruit Juices. Journal of Nutrition and Food Science, 2014; 19(2): 108-114.

22. Aboul-enein, A. M., El-Ela, F. A., Shalaby, E. A., and El-Shemy, H. A. Traditional Medicinal Plants Research in Egypt : Studies of Antioxidant and Anticancer Activities. Journal of Medicinal Plants Research, 2012; 6(5): 689-703.

23. Puspitasari, M. L., Wulansari, T. V., Widyaningsih, T. D., Maligan, J. M., and Nugrahini, N. I. P. Aktivitas Antioksidan Suplemen Herbal Daun Sirsak (Annona muricata L.) dan Kulit Manggis (Garcinia mangostana L .). Jurnal Pangan dan Agroindustri, 2016; 4(1): 283-290.

24. Suryani, N. C., Permana, D. G. M. and Jambe, A. A. G. N. A. 2016. Pengaruh Jenis Pelarut Terhadap Kandungan Total Flavonoid dan Aktivitas Antioksidan Ekstrak Daun Matoa (Pometia pinnata). Tugas Akhir. Diterbitkan, Fakultas Teknologi Pertanian Universitas Udayana. Badung.

25. Nandhakumar, E. and Indumathi, P. In vitro Antioxidant Activities of Methanol and Aqueous Extract of Annona squamosa ( L .) Fruit Pulp. Journal of Acupuncture and Meridian Studies, 2012; 6(3): 142-148.

26. Gavamukulya, Y. 2014. Phytochemical Composition, Anti-oxidant and In vitro Cytotoxic Properties of Extracts of Leaves of Annona muricata (Graviola ). Thesis. https://www. researchgate.net/publication/281089798

27. Widyanto, R. M., Putri, J. A., Rahmi, Y., Proborini, W. D., and Utomo, B. Aktivitas Antioksidan dan Sitotoksisitas in vitro Ekstrak Metanol Buah Nanas (Ananas comosus) pada Sel Kanker Payudara T-47D. Jurnal Pangan dan Agroindustri, 2020; 8(2): 95-103 